\title{
THE LEVEL OF EDUCATIONAL PROCESS, INFORMATION TECHNOLOGY AND ICT COMPETENCES SYNTHESIS AT ELEMENTARY SCHOOLS IN SICHUAN PROVINCE (CHINA)
}

\author{
Qianjun TANG, Leshan Normal University, China \\ Jitka LAITOCHOVÁ, David NOCAR, Tomáś ZDRÁHAL, \\ Univerzita Palackého v Olomouci, Česká republika
}

Přijato: 7. 6. 2017 / Akceptováno: 20. 11. 2017

Typ článku: Výzkum

DOI: $10.5507 /$ jtie.2017.029

Abstract: In the spring of 2017 the survey was conducted on 119 mathematic teachers from 12 elementary schools located in Leshan, Chendu, and Meishan all in Sichuan province in China. The authors wanted to know about the teachers' ICT skills and the use of ICT during their instruction. Based on the data analysis the authors resulted as follows: Teachers have recognized the strong impact force of ICT in education; Teachers have many good ideals in their instruction but can't implement them for lacking some necessary advanced ICT skills; Coming to the proper application ICT, namely, the aspect of the depth fusion of education and ICT they think it is difficulty in looking for the connections between ICT and education. Authors give some suggestions on carrying forward the depth fusion of ICT and education in conclusion.

Key words: Math Education, Math Teacher, ICT, Educational Informatization

\section{ÚROVEŇ SYNTÉZY EDUKAČNÍHO PROCESU, INFORMAČNÍCH TECHNOLOGIÍ A ICT KOMPETENCÍ UČITELŮ NA ZÁKLADNÍCH ŠKOLÁCH V PROVINCII S'-ČCHUAN (ČÍNA)}

Abstrakt: Na jaře 2017 bylo provedeno dotazníkové šetření za účasti 119 učiteli̊ matematiky na dvanácti základních školách ve městech Leshan, Chendu a Meishan v provincii $S^{\prime}$-čchuan v Činè. Cílem bylo zjistit úroveñ ICT kompetencí učitelì a využiváni ICT ve výuce matematiky. $Z$ analýzy dat vyplynuly následující závěry: Učitelé přikládaji velký důraz implementaci ICT do vzdělávání; Učitelé mají mnoho námětů $k$ využití ICT ve výuce, které nejsou schopni vždy zrealizovat, nebot’ jejich ICT kompetence nejsou dostatečné; Správná aplikace ICT do vzdělávacího procesu souvisi se správnou úrovni syntézy ICT a ostatnich aspektů vzdělávacího procesu, jejiž nalezení bývá obtižné. V závěru autoři předkládaji návrhy na dosažení potřebné úrovně syntézy vzdělávacího procesu s ICT.

Klíčová slova: výuka matematiky, učitel matematiky, ICT, informatizace.

*Autor pro korespondenci: david.nocar@upol.cz 


\section{1 Úvod}

Po vydání dokumentu Ten-Year Development Plan of Educational Informatization (2011-2020) Ministerstvem školství Číny, ve kterém vyjádřilo stanovené cíle informatizace vzdělávání, kterých má být dosaženo do roku 2020 a především v souladu s plánem třinácté pětiletky Č́ny (China's 13th Five-Year Plan) formulovaného na základě doporučení Ústředního výboru Komunistické strany Číny, došlo v Číně k velkým změnám v oblasti vzdělávání. Do poloviny loňského roku získalo v Číně 87 \% základních a středních škol prrístup k internetu a 80 \% učeben na základních a středních školách bylo vybaveno multimediálním zařízením (MoE, 2016). Př́stupy na podporu vzdělávání dané Národní platformou veřejných vzdělávacích zdrojů (The National Public Educational Resource Service Platform) a Národní platformou veřejných služeb pro řízení vzdělávání (The National Public Management of Education Service Platform) jsou k dispozici již několik let. Je zde již více než 5 milionů učitelů, kteří se aktivně účastní události „Co učitel to skvělý kurz, co kurz to skvělý učitel" ("One Teacher One Excellent Course, One Course One Famous Teacher"). Např. v roce 2016 byly na tuto veřejnou platformu vloženy 4 miliony kurzů (Chen Lin, 2017). Ke konci roku 2016 již absolvovalo školení v ICT dovednostech více než 10 milionů učitelů.

Z rozhovorů s učiteli z Č́ny vyplývá, že v Číně existuje propastný rozdíl mezi různými regiony, nebot' Čína je rozsáhlá země. Stejně je tomu i v oblasti vzdělávání, což v současnosti představuje především propast digitální. Tato digitální propast je způsobena díky nerovnováze rozvoje různých regionů, jako je např. rozdíl mezi městy a venkovem, východem a západem Č́ny, běžnými školami a klíčovými školami apod. Ve skutečnosti je více zřejmý rozdíl $\mathrm{v}$ hardwaru či infrastruktuře než $\mathrm{v}$ softwaru či dovednostech vyučujících. Přestože většina učitelů absolvovala školení v oblasti ICT dovedností, jak moc to ale zvýšilo jejich kompetence k využívání informačních a komunikačních technologií a jak moc využívají těchto technologií ve výuce, je druhá věc. Ještě horším případem je nedotčené vybavení pokryté prachem na některých venkovských školách na západě Číny. Navíc co se týče vybavení, existuje zde další fenomén, nebot' každá mince má dvě strany. Jednou je vzdělávání se během každodenní práce, druhou možností jsou veřejné kurzy. Všichni z nás si uvědomují důležitost ICT ve vzdělávání a věříme, že ICT se začlení do vzdělávacího procesu, tj. do výuky. Avšak co by se mělo dělat a jak naplno využívat možností ICT, je dilema pro většinu z nás včetně učitelů, autorů a politiků. Jedním z nejžhavějších témat v těchto letech v Číně je hloubka fúze ICT a vzdělávacího procesu.

\section{Koncepce a aplikace ICT do vzdělávání v Číně}

Informační a komunikační technologie představují aplikaci počítačů a komunikačních zařízení k ukládání, přijímání, přenosu a zpracovávání dat často v kontextu obchodním či podnikovém (Daintith, 2009). Kromě toho se aplikují především v návrhu, vývoji, instalaci a rozvoji informačních systémů a softwaru. ICT jako mikropočítače, Internet, e-learning, online zdroje, virtuální školy atd. si po vstupu do oblasti vzdělávání získaly př́zeň jak učitelů, tak studentů. Integrace ICT do vzdělávání se týká především využívání technologií ke komunikaci, práce s daty a ukládání dat s dopadem na znalosti žáků.

První fázi aplikace ICT do vzdělávání nazýváme pouze jako integraci nebo integraci ICT do ostatních předmětů. Během této první fáze představovala integrace: rozvoj multimediálních vzdělávacích objektů, digitalizaci učebních textů apod; důraz na infrastrukturu, zaměření na hardware, zařízení a vybavení; posílení ICT dovedností učitelů 
a jejich vybavenosti pro potřeby výuky. Reformátoři doufali, že za pomoci ICT se zlepší výsledky žáků a studentů, doufali především ve funkci ICT jako podpory k zlepšení vzdělávání přsesto ne jako nástroj nepostradatelný.

Později někteří reformátoři nabídli nový koncept - hloubku fúze (intenzitu či úroveň integrace popř. až splynutí), která představuje fúzi ICT a vzdělávacího procesu. Jedná se o efektivní integraci informačních technologií v různých oborech $\mathrm{k}$ vytvoření nového typu výukového prostředí, kde by byla lépe vidět vedoucí role učitele a status žáků či studentů, kde se budou moci skutečně projevit tvůrčí duch a praktické schopnosti žáků a studentů. Jedná se o integraci tří základních atributů: vytvoření nového výukového prostředí; realizace nového způsobu výuky; změna tradiční struktury výuky (He Ke-Kang, 2007). Tato hloubka fúze zdůrazňuje revoluci základní struktury vzdělávání, která není postupně pomalu začleňována, ale je zcela revoluční. Stejně tak vyžaduje Národní plán pro vzdělávací technologie (National Education Technology Plan) z roku 2016, aby pedagogové byli schopni být spolupracovníci $\mathrm{v}$ učení, $\mathrm{v}$ hledání nových poznatků a neustále získávali nových dovedností spolu s jejich studenty. Vedoucí pracovníci v oblasti vzdělávání by měli stanovit vizi k získávání vzdělávacích zkušeností, které poskytnou správné nástroje a podporu pro všechny žáky a studenty. Dále by se zainteresované strany v oblasti vzdělávání měly zavázat (stejně jako v USA) k tomu, že budou spolupracovat na využití technologií ke zlepšení vzdělávání. (U. S., DoE, 2015).

V Č́ně věnuje každá zainteresovaná strana velkou pozornost informatizaci vzdělávání včetně předních představitelů učitelů, fakult a dalších vzdělavatelů, výzkumníků, politiků, investorů, technických vývojářů, členové různých organizací, ale také žáci, studenti i jejich rodiny. $\mathrm{V}$ posledních letech bylo dosaženo mnoha důležitých politických rozhodnutí např. dokument Ten Years Planning of Educational Informatization (2011-2020) byl uveřejněn v březnu 2012; dokument The 13th Five Years Planning of Educational Informatization (2016-2020) vyšel v červnu 2016. Také Liu Yandong (vicepremiér Číny) přednesl projev o plné realizaci modernizace vzdělávacího procesu informatizací vzdělávání na setkání $\mathrm{v}$ rámci 2. národní tele-video-konference o informatizaci vzdělávání dne 19. listopadu 2015.

V současné době je vzdělávací strategií Č́ny, aby se modernizace vzdělávacího procesu stala skutečností díky probíhající informatizaci vzdělávání. Zavádění informatizace vzdělávání je systematický, obrovský a nesmírně složitý projekt. Proto se během procesu informatizace vzdělávání zaměříme pouze na potřebné kompetence učitelů.

Chce-li obyvatelstvo Č́ny zůstat globálně konkurenceschopné a rozvíjet zainteresované občany, měly by školy rozvíjet dovednosti a odborné znalosti 21 . století v průběhu vzdělávání. Sem patří rozvoj kritického myšlení, komplexní řešení problémů, spolupráce a zapojení multimediální komunikace do výuky tradičních akademických předmětů (Bishop, 2013). Kromě toho by žáci a studenti měli mít př́ležitost rozvinout své kompetence k učení a přesvědčení, že jsou schopni ve škole dosáhnout úspěchu. Jak již ale bylo uvedeno výše, vyvstává otázka, jaká je role nebo jaké jsou kompetence učitelů v procesu informatizace vzdělávání?

Prostřednictvím moderních informačních a komunikačních technologií, jako jsou videokonference, QQ, WeChat a weby sociálních sítí se mohou učitelé spojit s dalšími pedagogy a odborníky v rámci své komunity nebo i celého světa, aby si rozšíríli obzor a vytvořili si tak těmito novými možnostmi nové prŕiležitosti uplatnitelné ve výuce. Učitelé potřebují získávat dovednosti pro výuku v novém prostředí informačních technologií. 
Kromě toho učitel potřebuje navrhnout propojení relevantních zkušeností a výuky prostřednictvím informačních technologií. V procesu výuky hraje učitel roli průvodce, facilitátora a motivátora. Učitelé musí opustit své zaběhnuté přípravy a metody s dưrazem na nové metody využívající technologie pro podporu výuky. Efektivní využívání technologií není volitelným doplňkem či dovedností, u které bychom mohli očekávat, že ji učitelé získají při výuce. Učitelé potřebují vědět, jak využít technologií při realizaci výuky a naplňování státních vzdělávacích standardů již od prvního dne výuky. (U. S., DoE, 2015).

\section{Výzkumné šetření}

S cílem seznámit se s aktuálním stavem ICT kompetencí učitelů a implementací ICT ve výuce na základních školách bylo během února a března 2017 na školách v provincii S'-čchuan provedeno výzkumné šetření. Šetření se zúčastnilo 119 učitelů na dvanácti školách. (Výzkumné šetření bylo realizováno jako součást specifického výzkumného projektu ICT ve výuce matematiky na moravských základních školách (Česká republika) a školách provincie $S^{\prime}$-čchuan (Čína)). Kromě tohoto šetření realizovaného v Č́ně v provincii $\mathrm{S}^{\prime}$-čchuan probíhají podobná šetření $\mathrm{k}$ připravenosti učitelů matematiky i v České republice (např. Dofková, 2016; Bártek, Nocar, Wossala, 2016; Bártek, Nocar, Laitochová, 2017).

Aby bylo šetření co nejobjektivnější, byly uplatněny následující zásady: do šetření byly zapojeny pouze učitelé základních škol, a to jak prvního, tak druhého stupně; ve stejném poměru byly zastoupeny školy městské a školy prríměstské. Konkrétně byly zapojeny školy ve městech Leshan, Chengdu a Renshou County. Někteří zapojení učitelé pocházejí z prestižních škol ve velkých městech, jako je např. Chengdu No. 7, jiní pocházejí z menších měst či okresů, jako je např. Leshan No. 5, základní školy Shawan, další pocházeli ze škol venkovských, jako jsou např. Renshou Liren, Shawan Tashui ad.

Při realizaci dotazníkového šetření k zjištění ICT kompetencí učitelů, nemůžeme opomenout ani specifické vlastnosti každého jednotlivce, jako je např. věk, délka praxe, vyučované předměty, dosažené vzdělání apod. Navíc byly realizovány rozhovory s učiteli, a to bud' př̀i osobním setkání, nebo přes online komunikační nástroje (např. QQ, WeChat apod.).

Výzkumné šetření mělo prozkoumat některé aspekty vztahu učitelů k procesu informatizace vzdělávání, jako jsou např. ICT kompetence učitelů včetně využívání ICT ve výuce, využívání a příprava DLO (DLO je zkratka pro digitální výukové objekty z angl. Digital Learning Object, jako jsou např.: elektronické textové dokumenty, prezentace v PowerPointu, Excel soubory, animace, simulace, didaktické hry apod., více o DLO např. Bártek - Nocar, 2016), používání veřejně dostupných zdrojů, model fúze ICT do vzdělávacího procesu atd.

Sběr dotazníků probíhal osobně a poštou. O příslušných kompetencích byly vedeny diskuse s učiteli i vedoucími ICT odborů v oblasti Shawan a pomocí nástrojů QQ a WeChat $\mathrm{s}$ učiteli z oblasti Leshan. Př́spěvek prezentuje výstupy analýzy dat některých ICT dovedností učitelů sledovaného regionu a zkoumá možnosti, jak tyto dovednosti rozvíjet. 


\section{Analýza dat}

Během února a března 2017 bylo osobně a poštou nashromážděno 119 dotazníků od učitelů sledovaného regionu. Některé základní informace o zúčastněných učitelích prezentují Obr. 1 a Obr. 2.

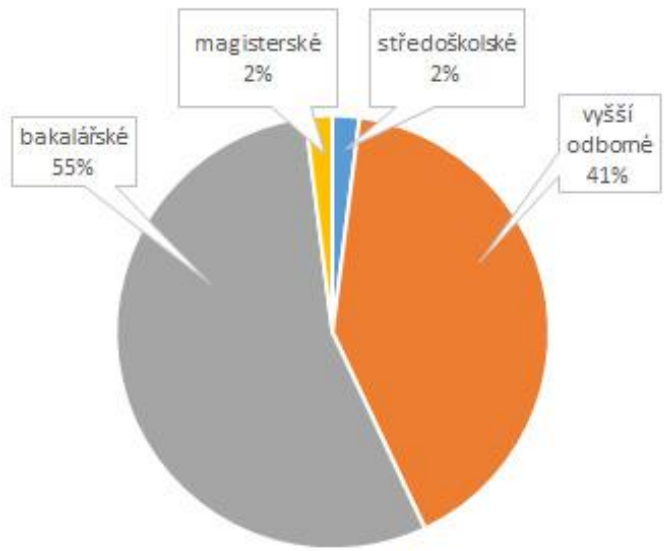

\section{Dosažené vzdělání}

Obrázek č. 1: Některé základní informace o zúčastněných učitelich (dosažené vzdělání)

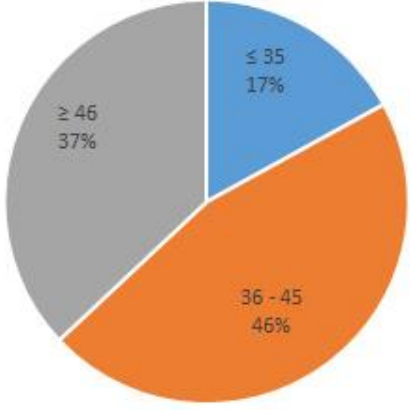

Věk

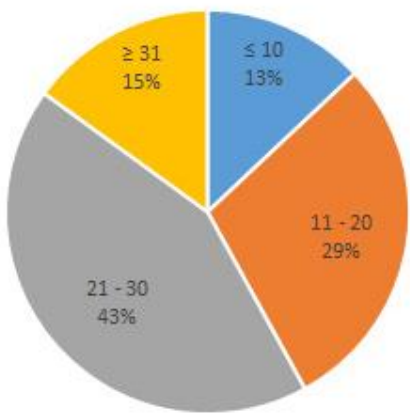

Délka praxe

Obrázek č. 2: Některé základní informace o zúčastněných učitelich (věk, délka praxe)

Z výše uvedených informací můžeme chápat obtížnost procesu informatizace vzdělávání ve školách, nebot' pouze $2 \%$ učitelů dosáhlo magisterského stupně vzdělání, $55 \%$ učitelů má bakalářský stupeň vzdělání a $41 \%$ učitelů má vyšší odborné vzdělání (Secondary Professional School; studium v rozsahu dvou let; bez vysokoškolského stupně vzdělání). 
Obecně lze předpokládat, že čím vyšší stupeň vzdělání nebo čím delší je příprava během studia, tím snadněji se poté učí nové znalosti a dovednosti. V současnosti je dalším negativním faktorem i to, že v oblasti vzdělávání je př́lišs vysoký podíl starších učitelů. Starší učitelé dávají najevo, že je pro ně obtížnější se učit novým ICT dovednostem a někteří z nich se už ani nechtějí učit novým věcem a nechtějí implementovat tyto technologie do své výuky. Více než polovina učitelů působí ve škole již přes dvacet let a s tím samozrejmě souvisí, že čím déle je učitel $\mathrm{v}$ praxi, tím je starší. Většina dotazovaných učitelů začala pracovat ve školství před rokem 1996 a 37 \% z nich nastoupilo do školy v osmdesátých letech. Z toho plyne, že přibližně polovina dotazovaných učitelů absolvovala vzdělávání v 80 . letech.

V těchto letech byla ekonomika Číny ještě velmi zaostalá, natož tak disponovat počítači v oblasti vzdělávání. Na základě toho můžeme konstatovat, že přibližně $50 \%$ učitelů nikdy neměla možnost použít počítač během svého vzdělávání.

V dotazníkovém šetření se vyskytovaly položky zjišt'ující stav základních ICT dovedností, jako je využívání MS Word, MS PowerPoint and MS Excel a frekvence využívání DLO ve výuce (tj. jak často je využíváno digitálních výukových objektů $\mathrm{v}$ hodinách matematiky - v kolika hodinách $\mathrm{k}$ celkovému počtu hodin výuky matematiky ve školním roce). V této oblasti základních ICT dovedností již bylo provedeno podobné šetření začátkem roku 2016. Po aktuálně provedeném šetření se můžeme podívat na srovnání získaných dat z roku 2016 a z roku 2017 tak, jak ukazují Obr. 3 a Obr. 4.

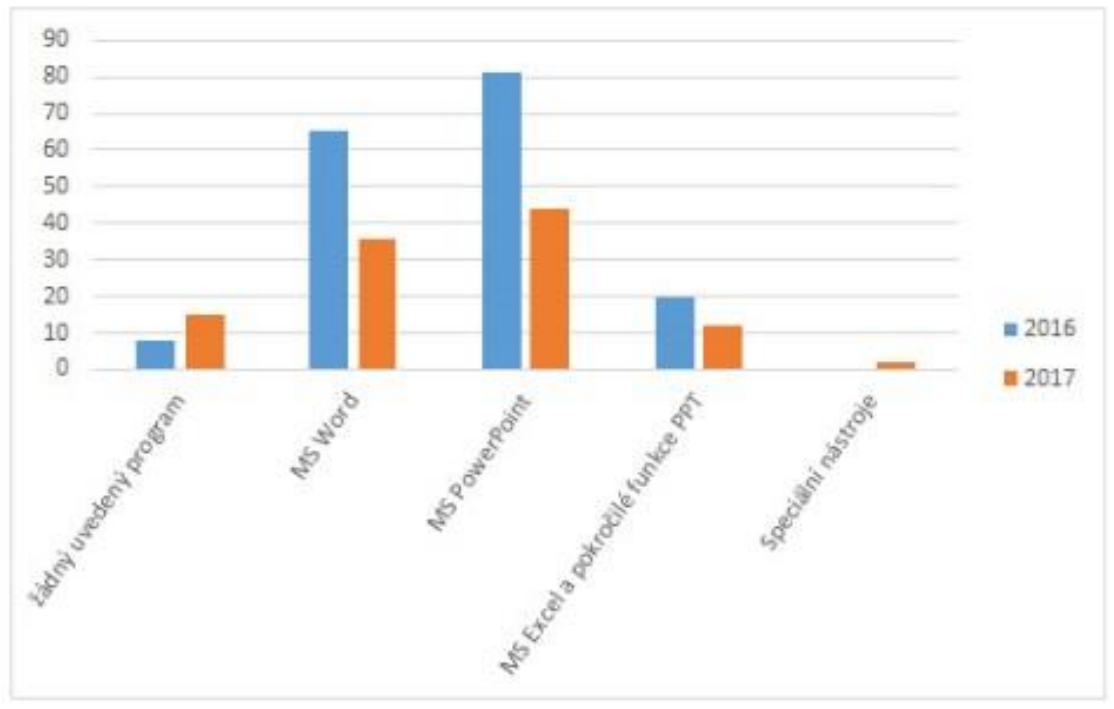

Obrázek č. 3: Využívání MS Office 


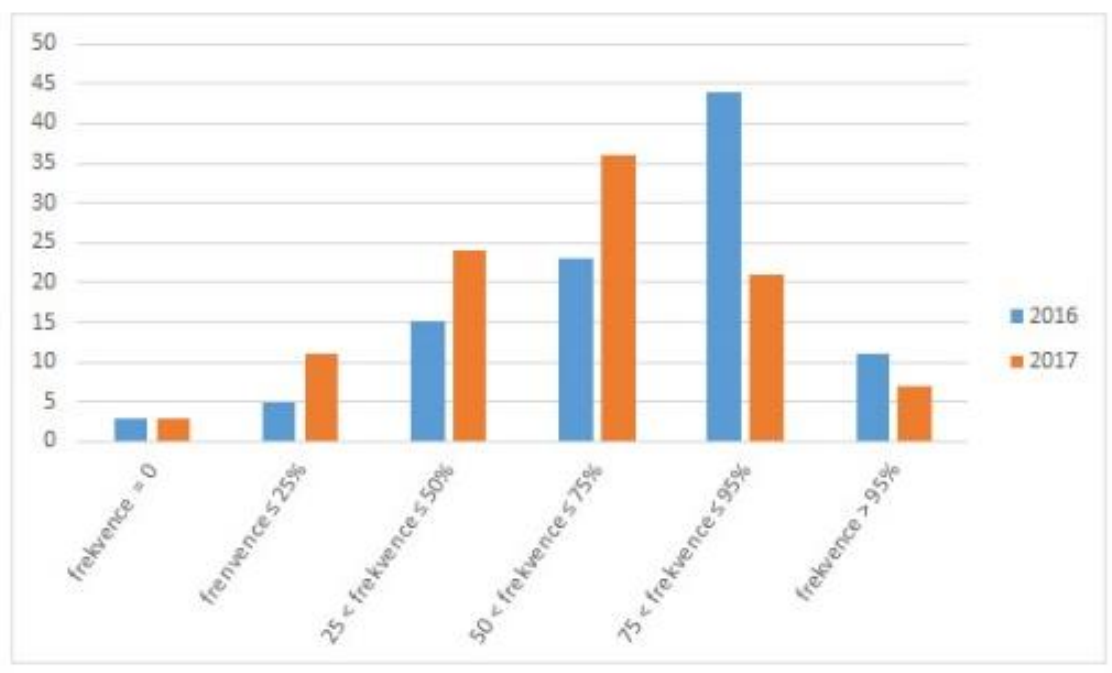

Obrázek č. 4: Frekvence využiváni DLO

Poznámka: Na dotazníku použitém při výzkumném šetření realizovaném v roce 2016 spolupracovali kolegové z Leshan Normal University v Číně a dotazník použitý při výzkumném šetření realizovaném v roce 2017 navrhli pracovníci Katedry matematiky Pedagogické fakulty Univerzity Palackého v Olomouci v ČR. Bylo nevyhnutelné zdůraznit jiné klíčové body z oblasti ICT kompetencí, přičemž podobná témata pak ale byla účastníky chápána odlišně. Navíc v roce 2016 se šetření účastnilo 143 učitelů, a to i jiných předmětů než jen matematiky, kdežto v roce 2017 se šetření účastnilo 119 učitelů, kteří všichni vyučují sledovaný předmět - matematiku.

Z obr. 3 je patrné, že dovednosti ve využívání nástrojů MS Office a především dalších specializovaných nástrojů jsou pod očekáváním, přestože tyto nástroje jsou základním kamenem obsluhy PC, informační gramotnosti a dalšího vzdělávání v oblasti ICT v Číně. Téměř polovina učitelů se ohodnotila podprůměrně a přibližně $15 \%$ učitelů matematiky nepoužívají nástrojů MS Office vůbec, natož aby byli schopni používat některých dalších specializovaných nástrojů. Kromě toho jen velmi malá část učitelů dovede $\mathrm{v}$ aplikacích MS PowerPoint a MS Excel použít pokročilejších nástrojủ. Zato z obr. 4 můžeme vyčíst, že více než 60 \% učitelů využívá ve své výuce DLO s frekvencí vy̌šší než 0,5 (frekvence $>50 \%)$. Z toho vyplývá, že i pressto se většina učitelů snaží realizovat výuku kvalitně a moderně a využívají $\mathrm{k}$ tomu většinou již předpřipravené materiály. $\mathrm{K}$ zaznamenávání frekvence využívání DLO v letech 2016 a 2017 použijeme Likertovu škálu. Vyloučíme-li zanedbatelnou položku frekvence $=0$, zůstane nám pět různých stupňů frekvence, kterým přiřadíme bodovou škálu 1 až 5 . Poté již můžeme spočítat celkové skóre každého roku $\mathrm{S}=\Sigma \mathrm{f}_{\mathrm{i}} * \mathrm{n}$, kde i představuje stupeň frekvence a hodnota $\mathrm{n}$ je postupně od 1 do 5 . Jednoduchým výpočtem získáme hodnoty S2016=3,35 a S2017=2,86. Z výsledných 
hodnot je patrné, že počet učitelů matematiky využívajících DLO ve své výuce je o 10 \% nižší než je tomu obecně u učitelů základní školy bez ohledu na vyučovaný předmět.

Tento rozdíl možná souvisí se specifickým pojetím výuky matematiky u učitelů, kteří považují matematiku za předmět, který si vystačí s logickým uvažování a představivostí a o to méně potřebuje vizuální interpretaci.

Ne více než $5 \%$ učitelů považuje DLO a obecně ICT za málo přínosné pro výuku oproti zbývajícím 95 \% učitelů, kteří si myslí, že tyto technologie a DLO mají velký vliv na vzdělávání, a proto se snaží tyto technologie a materiály ve své výuce použivat. Při rozhovoru zjišt'ujícím, v čem je hlavní prríčina toho, proč si nepřipravují sami DLO pro svou výuku popřr. jen zřídka sami nějaké DLO vytvoří či nějaké volně dostupné sami upraví dle svých potřeb, odpovídají nejčastěji v souvislosti se dvěma faktory: 59 \% učitelů uvádí, že nemají potřebné dovednosti; dvě třetiny učitelů si myslí, že k tomu ani nemají potřebné softwarové nástroje.

\section{Závěr a doporučení}

Z výsledků dotazníkového šetření, analýzy získaných dat a především z rozhovorů s učiteli můžeme konstatovat, že ICT kompetence učitelů v provincii $\mathrm{S}^{\prime}$-čchuan nejsou na optimální úrovni. Musíme zmínit, že každý učitel základní školy absolvoval v posledních deseti letech prezenčně nebo online v průměru alespoň dvakrát nějaký kurz ICT a celkem bylo proškoleno více než 80 zapojených učitelů. Na příčiny aktuálního stavu můžeme nahlížet z několika úhlů pohledu: učitelé považují za komplikované chtít pomoc od své školy; učitelé v mnoha případech nemají ani základní znalosti v oblasti ICT; implementace ICT je rychlejší než s tím související získávání potřebných ICT dovedností učitelů. Jednou z nejdůležitějších otázek, které tak dnes čelí základní vzdělávání v Číně, je nedostatek kvalifikovaných učitelů. Nicméně není možné vyškolit v ICT dovednostech všechny učitele, když není, kdo by je to naučil. V první řadě musí existovat způsob, jak vyškolit stávající učitele k získání potřebných ICT dovedností, a to především v oblasti základního vzdělávání. Na základních školách, kde učitel vede výuku všech předmětů, může existovat cesta díky výuce předmětu ICT. Ve světě je běžné, že specialisti z oboru ICT školí učitele předmětu informatiky a ti pak mohou ve svých školách školit další učitele ostatních předmětů. V souladu s dokumenty ministerstva školství Číny The Criterion of Capacity of K12 Teachers in Application IT (Trial), The Training Criterion of K12 Teachers in Application IT (Trial) (MoE of the P. R. C.) a dle aktuální situace učitelů, je potřeba připravit rámec základních ICT kompetencí učitelů. Základní obsah této př́ípravy by mohl být rozdělen do následujících 5 modulů:

Modul 1: Práce $\mathrm{s}$ běžnými medii, základní obsluha $\mathrm{PC}$ a použíání běžného kancelářského softwaru. Konkrétní náplní by byla obsluha PC s MS Windows a základními programy MS Office (Word, Excel, PowerPoint). U učitelů informatiky by se dále prohlubovali ICT dovednosti a prozkoumávali by se pokročilejší funkce daných programů včetně volání funkcí WIN64 API (Application Programming Interface), používání pokročilejších funkcí MS Word, MS Excel a MS PowerPoint.

Modul 2: Příprava multimediálních výukových objektů zejména animací využitím nástrojů Adobe Flash včetně objektově orientovaného programovacího jazyka ActionScript. 
Modul 3: Obsah a návrh programu s důrazem na prezentovanou myšlenku, informaci, obsah bez hlubšího porozumění konkrétního programovacího jazyka. Zvolme např. Visual Basic s využitím VBA (Visual Basic for Applications) k rozšíření funkcí MS Office.

Modul 4: Základy práce s databázemi, jednoduché dotazy pomocí SQL (Structured Query Language), což by mělo mít za následek porozumění ukládání a uspořádání dat v počítači, nebot' žijeme především v době dat. SQL je standardní dotazovací jazyk, který může být použit společně s většinou programovacích jazyků.

Modul 5: Práce $\mathrm{v}$ síti, návrh a vývoj webových stránek, práce $\mathrm{s}$ online zdroji (vyhledávání a filtrování informací) a identifikace vhodných zdrojů pro podporu výuky. Při př́ípravě webových stránek by měla být větší pozornost věnována dynamickým webovým stránkám, odkazům na databáze a použití HTML5 (5. verze hypertextového značkovacího jazyka - HyperText Markup Language).

Učitelé by měli být žákovy průvodci, facilitátoři a motivátoři. Pedagogům by měly být dostupné informace prostřednictvím vysokorychlostního internetu. Žákům by měli učitelé pomáhat, jak přistupovat $\mathrm{k}$ online informacím, jak se zapojit do simulací reálných situací, používat technologie $\mathrm{k}$ dokumentaci svého světa a pomáhat žákům zkoumat problémy a hluboce se zamyslet nad svým vzděláváním. Učitelé také mohou využít tyto výhody pro sebe, nebot' sami procházejí změnami v novém pojetí výuky od zaměření na to, co učí, k tomu co a jak se mohou žáci naučit a ukázat, co umí. (U. S., DoE, 2015).

$\mathrm{Na}$ závěr bychom mohli uvést, že posláním každého nástroje či metody je jejich uplatnitelnost v našem každodenním životě, v každodenní práci, ale základním kamenem je potřeba disponovat př́slušnými dovednostmi k jejich efektivnímu využívání.

Výzkumné šetření i článek vznikl v rámci realizace specifického výzkumného projektu ICT ve výuce matematiky na moravských základních školách (Česká republika) a školách provincie S'-čchuan (Čína), číslo projektu: IGA_PdF_2017_014 realizovaného na Katedře matematiky Pedagogické fakulty Univerzity Palackého v Ōlomouci a 2. pilotního šetření projektu na komplexní reformu školství v provincii S'-čchuan Depth integration of modern education technology into the primary and lower secondary school education.

\section{Literatura}

Bártek, K. \& Nocar, D. (2016). Digital Learning Objects as a Support for New Teaching Methods. INTED2016 Proceedings. Valencia: IATED. pp. 2583-2586. ISSN 2340-1079. DOI 10.21125/inted.2016.1552.

Bártek, K. \& Nocar, D. (2016). Mathematic Education Support by Digital Learning Objects. EDULEARN16 Proceedings. Barcelona: IATED. pp. 3249-3253. ISSN 23401117. DOI 10.21125/edulearn.2016.1707.

Bártek, K., Nocar, D. \& Laitochová, J. (2017). Digital Learning Objects by the View of Czech Mathematics Teachers. EDULEARN17 Proceedings. Barcelona: IATED.

Bártek, K., Nocar, D. \& Wossala, J. (2016). ICT Training of Mathematics Teachers in the Context of Their Current Educational Needs. ICERI2016 Proceedings. Sevilla: IATED. pp. 336-341. ISSN 2340-1095. DOI 10.21125/iceri.2016.1081. 
Bishop, J. (2013). Framework for 21st century learning. Partnership for 21st Century Learning. Dostupné na: 〈http://www.p21.org/our-work/p21-framework>.

Daintith, J. ed. (2010). A Dictionary of Physics, 6th Edition. Oxford University Press. ISBN-13: 978-0199233991.

Dofková, R. (2016). Přesvědčení o připravenosti budoucích učitelů matematiky jako didaktická výzva primárního vzdělávání. Olomouc: Univerzita Palackého v Olomouci. ISBN 978-80-244-5047-6. DOI 10.5507/pdf.16.24450476.

He Ke-Kang \& Wu Juan. (2007). Integrating Information Technology into Curriculum. Higher Education Press.

Chen Lin, Yang Ying \& Hua Lulu. (2017). Informatization Impelled Education towards New Development in the First Year of the 13th Five Years Planning. China Educational Technology, 2017(2). pp. 65-69.

Ministry of Education of the P. R. C. (2014). The Criterion of Capacity of K12 Teachers in Application IT (Trial). Dostupné na: <http://www.moe.edu.cn/publicfiles/business/ htmlfiles/moe/s6991/201406/170123.html>.

Ministry of Education of the P. R. C. (2014). The Training Criterion of K12 Teachers in Application IT (Trial). Dostupné na: <http://www.moe.edu.cn/publicfiles/business/ htmlfiles/moe/s7034/201406/170126.html>.

Ministry of Education of the P. R. C. (2016). Ten Years Planning of Educational Informatization (2011-2020). Dostupné na: <http://www.edu.cn/xxh/focus/zc/201606/ t20160621_1417428.shtml>.

U. S. Department of Education. (2016). 2016 National Education Technology Plan. Dostupné na: 〈https://tech.ed.gov/files/2015/12/NETP16.pdf〉. 